\title{
Effect of fibrous and starchy carbohydrates in concentrates as supplements in a herbage-based diet for high-yielding dairy cows
}

\author{
H. VALK, H. W. KLEIN POELHUIS \& H. J. WENTINK \\ Research Institute for Livestock Feeding and Nutrition, P.O. Box 160, NL 8200 AD Lelystad, \\ Netherlands
}

Received 27 February 1990; accepted 11 April 1990

\begin{abstract}
The effects of two concentrates composed of different carbohydrate sources (beetpulp versus maize) on intake, digestibility, yield and compositon of milk by high-yielding dairy cows fed fresh herbage indoors was investigated. In 1988 two diets and in 1989 three diets were used with nine cows per diet. In 1989 concentrates were supplied on an equal amount of DM and in 1989 on an equal amount of energy. The animals received the concentrates after milking time. In 1988 the experimental period lasted for 8 weeks and in 1989 for 10 weeks. In 1988 intake of herbage DM tended to be higher on the maize-enriched diet, resulting in a significantly $(P<0.05)$ higher intake of $\mathrm{OM}$ and energy. Nitrogen intake was also significantly $(P<0.001)$ higher but mainly as a result of an unintentional high crude protein content of the maize concentrate. In 1988 and 1989 the apparent digestibility of $\mathrm{N}$ was significantly $(P<0.05)$ higher on the starchy as compared with the fibrous diet. In 1988 the milk yield on the maize-enriched diet was significantly $(P<0.05)$ higher than on the beetpulp-enriched diet partly due to a higher intake of energy. In 1989 no significant effect of carbohydrate source on milk yield was observed. Milk fat concentration declined as the proportion of starch in the diet increased. Milk protein content was not significantly affected by the source of carbohydrate.
\end{abstract}

Keywords: dairy cows, herbage, supplementation, carbohydrates, digestibility, milk production

\section{Introduction}

Rations containing only herbage are unable to meet the energy requirement of highyielding dairy cows. Reasons for this phenomenon are firstly the low DM intake, secondly the inbalance between energy and protein and thirdly the nature of protein (rapidly degradable) in herbage. Excess of $\mathrm{N}$ fertilizer supply as occurs in the Netherlands results in a high degradable protein content, which leads to a low efficiency of $\mathrm{N}$ utilization and increased urinary $\mathrm{N}$ losses especially as urea. Twigge et 
al. (1988) stated that an excess of rumen-degradable protein and the consequential need to excrete large amounts of urea also has an effect on the cow's energy balance. Furthermore, they used data of Blaxter (1962) and calculated that in practical grazing regimens a surplus of $500-1000 \mathrm{~g}$ rumen-degradable protein is not unusual and could account for losses equivalent to an energy value of 1.3 to $2.6 \mathrm{~kg}$ fat-corrected milk (FCM).

Energy supplements are needed to improve the ruminal imbalance between degraded protein and energy supply for optimum microbial capture of degraded $\mathrm{N}$ (Beever et al., 1986). Supplementation of herbage with energy-rich feedstuffs may also improve the energy intake. This response to supplementation depends on the rate of substitution and on the energy content of the supplement. In order to measure the rate of substitution, most experiments have been undertaken in the field to enable the effects of herbage and supplement allowance on the intake of herbage (Meijs et al., 1984; Stakelum et al., 1986). Little is known about the effects of a supplement on the utilization of nutrients from a herbage-based diet. For making a good comparison between the effects of different supplements on the utilization of nutrients, feeding trials indoors must be carried out with a fixed allowance of herbage and supplements to provide the same DM or energy intake.

A useful supplement to herbage in the Netherlands is maize silage and the effect of this supplement will be described in another paper. However in the western and northern parts of the country, climatic and soil conditions prevent growing maize silage and, elsewhere the area for maize is also limited. Therefore, low-N concentrate-mixtures can be used to improve the utilization of nutrients. By using a concentrate-mixture based on barley or cassava versus beetpulp Meijs et al. (1986) and Kibon et al. (1987) observed a higher intake of herbage when barley or cassava in the concentrates was replaced by beetpulp. It seems that barley concentrate depressed the digestibility of herbage more than the beetpulp concentrate (ArriagaJordan et al., 1986). Stockdale et al. (1987) concluded that a maize- or sorghumbased concentrate-mixture resulted in a higher milk output than a barley-based concentrate. This was attributed to a slower rate of degradation of maize and sorghum starch as compared to barley starch. The rapid degradation of barley starch causes high VFA production and a decrease in $\mathrm{pH}$ (Sutton et al., 1987). Because of the nature of energy and protein in fresh herbage, it seems important to select supplements which not only provide energy as such, but also energy which is complementary in nature to the energy in grass. Starchy and fibrous concentrate-mixtures therefore were used as supplements because they were low in crude protein and the energy was supplied by slowly degradable starch (maize meal) and highly digestible cell walls (beetpulp).

The purpose of the experiments was to compare the utilization of energy and $\mathrm{N}$ and the lactational responses of dairy cows when maize or beetpulp were used in concentrate-mixtures as supplements in a herbage-based diet for high-yielding dairy cows. 


\section{Materials and methods}

\section{Animals and treatments}

Two experiments were carried out with high-yielding multiparous dairy cows, fed daily fresh-cut herbage indoors in 1988 and 1989, respectively. In 198818 cows and in 198927 cows were allocated on the basis of age, calving date, milk yield and compositon to 9 blocks of 2 and 9 blocks of 3 cows. Within blocks, cows were allotted to 2 or 3 treatments, respectively. The average data of milk performance of 9 cows per treatment, produced at the start of the experiments (actual lactation) and during the whole previous lactation, are given in Table 1. In 1988 fibrous (F88) and starchy concentrates (S88) and in 1989 fibrous (F89), starchy (S89) and the intermediate, indicated as fibrous/starchy concentrates (FS89) were used as supplements of a herbage diet. The concentrate-mixture in treatment FS89 contained an equal amount of beetpulp and maize meal. The composition and allowance of the concentrates are given in Table 2. In 1988 concentrate allowance was on the basis of an equal amount of dry matter and in 1989 on the basis of an equal amount of net energy. Concentrates were supplementary to fresh herbage in the grazing stage of maturity. The allowance of herbage was in $198813.2 \mathrm{~kg} \mathrm{DM} \mathrm{d}^{-1} \mathrm{cow}^{-1}$ and in $198914.4 \mathrm{~kg} \mathrm{~d}^{-1}$ cow ${ }^{-1}$. Herbage contained $85 \%$ perennial ryegrass and was daily cut from pastures, fertilized with $400 \mathrm{~kg} \mathrm{~N}$ per ha per year. $\mathrm{Cr}_{2} \mathrm{O}_{3}$ was used to estimate the faecal production and was included in a commercial compound feed, containing $1.37 \mathrm{~g} \mathrm{Cr} \mathrm{kg}^{-1}$ in 1988 and $2.74 \mathrm{~g} \mathrm{Cr} \mathrm{kg}^{-1}$ in 1989. Daily supply of these pellets was 2 and $0.8 \mathrm{~kg}$ in 1988 and 1989 respectively. The diets were offered for 8 weeks and for 10 weeks including a change-over period of 2 weeks for the two years respectively.

\section{Management}

- Cows were housed on tie standings with rubber mats and individual feeding facili-

Table 1. Average yield and composition of milk at the start of the experiments (actual lactation) and during the whole previous lactation of nine cows per treatment.

\begin{tabular}{|c|c|c|c|c|c|c|c|c|c|}
\hline \multirow[t]{2}{*}{ Group } & \multicolumn{5}{|c|}{ Actual lactation } & \multicolumn{4}{|c|}{ Previous lactation } \\
\hline & $\begin{array}{l}\text { lactation } \\
\mathrm{nr} \text {. }\end{array}$ & $\begin{array}{l}\text { stage } \\
\text { of } \\
\text { lact. } 1\end{array}$ & $\begin{array}{l}\text { milk } \\
(\mathrm{kg} \mathrm{d}-1)\end{array}$ & $\begin{array}{l}\text { fat } \\
(\%)\end{array}$ & $\begin{array}{l}\text { protein } \\
(\%)\end{array}$ & $\begin{array}{l}\text { milk } \\
(\mathrm{kg})\end{array}$ & $\begin{array}{l}\text { fat } \\
(\%)\end{array}$ & $\begin{array}{l}\text { protein } \\
(\%)\end{array}$ & $\begin{array}{l}\text { lactation } \\
\text { period } \\
\text { (days) }\end{array}$ \\
\hline F88 & 2.9 & 84 & 35.4 & 4.36 & 3.21 & 7890 & 4.74 & 3.42 & 308 \\
\hline S88 & 2.2 & 82 & 33.7 & 4.47 & 3.27 & 7499 & 4.87 & 3.53 & 327 \\
\hline F89 & 3.2 & 80 & 35.3 & 4.56 & 3.35 & 7530 & 4.60 & 3.47 & 304 \\
\hline S89 & 3.0 & 90 & 34.4 & 4.56 & 3.31 & 7440 & 4.64 & 3.40 & 304 \\
\hline FS89 & 3.0 & 89 & 34.2 & 4.58 & 3.39 & 7791 & 4.61 & 3.34 & 296 \\
\hline
\end{tabular}

1 Days in production before $1 / 5$. 
H. VALK, H. W. KLEIN POELHUIS AND H. J. WENTINK

Table 2. Ingredients and allowance of the concentrate-mixtures.

\begin{tabular}{lccccc}
\hline & F88 & S88 & F89 & S89 & FS89 \\
Ingredients $\left(\mathrm{g} \mathrm{kg}^{-1}\right)$ & & & & & \\
Beetpulp $\left(100-150 \mathrm{~g}^{\prime}\right.$ sugar $\left.\mathrm{kg}^{-1}\right)$ & 825 & - & 784 & - & 440 \\
Soybean hulls $\left(>310 \mathrm{~g}^{2}\right.$ crude fibre $\left.\mathrm{kg}^{-1}\right)$ & 150 & - & 100 & - & - \\
Maize meal & - & 475 & - & 874.5 & 440 \\
Maize bran & - & 500 & - & - & - \\
Animal fat & - & - & 25 & 25 & 25 \\
Cane molasses $\left(>450 \mathrm{~g}\right.$ sugar $\left.\mathrm{kg}^{-1}\right)$ & 25 & - & 50 & 50 & 50 \\
Minerals / vitamins & & & 41 & 50.5 & 45 \\
Allowance & & & & & \\
Concentrates $\left(\mathrm{kg} \mathrm{d}^{-1}\right.$ cow-1) & 7.0 & 7.0 & 8.0 & 7.4 & 7.7 \\
\hline
\end{tabular}

1 Hominy feed in USA.

ties. Herbage was offered frequently during the whole day, except during and immediately after milking. The $\mathrm{Cr}_{2} \mathrm{O}_{3}$ pellets were offered during milking time and the concentrates after milking in two equal amounts per day. Feed refusals were removed and weighed daily at 14:30 h.

\section{Measurements}

To calculate the fresh weight of the herbage allowance samples were taken daily and analysed for DM content by a quick method (Meijs, 1981). Net intake was measured on three consecutive days each week. On these days herbage was collected and sampled for chemical analysis and for determining in vitro digestibility. Herbage refusals were analysed only for DM and ash content. The $\mathrm{Cr}_{2} \mathrm{O}_{3}$ pellets were sampled every week and analysed for content of DM, ash and $\mathrm{Cr}$. The other concentrates were sampled at the start, in the middle and at the end of the experiments for chemical analysis and in vitro digestibility. Faeces were collected and sampled for measuring $\mathrm{Cr}$ content and chemical composition during the period from 06:30 $\mathrm{h}$ to 15:00 $\mathrm{h}$ at three consecutive days (Tuesday, Wednesday and Thursday). Cows were milked twice daily with milk weights recorded at each milking and milk samples collected during three consecutive days. Milk samples were analysed for fat (Netherlands Standardization Institute, NEN 962) and protein (International Organization for Standardization, ISO 5542).

\section{Statistical analysis}

Intake, digestibility of nutrients and milk performance data were completely randomized in block designs and were subjected to analysis of variance using the statistical package Genstat (Alvey et al., 1982). 


\section{Results}

\section{Animal health}

Two cows on treatment F88, one cow on F89 and one on S89 were assigned missing values in the analysis of the data. The reasons were teat injury, non-explainable feed intake problems and mastitis, respectively.

\section{Chemical composition and nutritive value}

The mean chemical compostition, net energy content and in vitro digestibility of the herbage and concentrates are given in Table 3. In 1988 crude protein content of herbage DM was much lower and crude fibre and sugar content were higher than in 1989. The differences in crude fibre, NDF, sugar and starch between the concentrates reflect the two types of carbohydrate sources. A higher crude protein and lower starch fraction of maize bran (= hominy feed - USA) than reported in the Dutch Feed Table, resulted in a higher crude protein and lower starch content of the concentrate used in treatment S88 than planned. The starch fraction of the concentrate used in treatment S89 was also lower than expected due to the lower starch content of the maize meal.

\section{Nutrient intake and digestion}

Although planned to be equal in 1988 dry matter intake on S88 tended to be higher $(P<0.06)$ than on F88 as a result of the higher herbage intake (Table 4). Intake of OM was significantly $(P<0.05)$ higher for cows fed the S88-diet than for cows fed the F88-diet. Net energy intake on S88 was higher than on F88 attributed to the

Table 3. Chemical composition, net energy and in vitro digestibility of the herbage and concentrates offered.

\begin{tabular}{|c|c|c|c|c|c|c|c|}
\hline & \multicolumn{2}{|c|}{ Herbage } & \multicolumn{5}{|c|}{ Concentrates used in treatment } \\
\hline & 88 & 89 & F88 & S88 & F89 & S89 & FS89 \\
\hline Dry matter $\left(\mathrm{g} \mathrm{kg}^{-1}\right)$ & 176 & 171 & 891 & 882 & 899 & 876 & 889 \\
\hline Ash $\left(\mathrm{g} \mathrm{kg}^{-1} \mathrm{DM}\right)$ & 99 & 105 & 81 & 58 & 100 & 65 & 86 \\
\hline Crude protein $\left(\mathrm{g} \mathrm{kg}^{-1} \mathrm{DM}\right)$ & 175 & 214 & 100 & 146 & 101 & 110 & 97 \\
\hline Crude fibre (g kg-1 DM) & 228 & 217 & 220 & 52 & 183 & 24 & 96 \\
\hline $\mathrm{NDF}\left(\mathrm{g} \mathrm{kg}^{-1} \mathrm{DM}\right)$ & 474 & 473 & 465 & 257 & 372 & 103 & 233 \\
\hline Sugar (g kg-1 DM) & 146 & 113 & 100 & 22 & 119 & 42 & 80 \\
\hline Starch $\left(\mathrm{g} \mathrm{kg}^{-1} \mathrm{DM}\right)$ & - & - & - & 468 & - & 567 & 319 \\
\hline Net energy (VEM $\left.\mathrm{kg}^{-1} \mathrm{DM}\right)$ & 958 & 969 & 1040 & 1102 & 1066 & 1190 & 1140 \\
\hline \multicolumn{8}{|l|}{ In vitro organic matter } \\
\hline digestibility ( $\left.\mathrm{g} \mathrm{kg}^{-1} \mathrm{OM}\right)$ & 809 & 805 & 859 & 890 & 846 & 863 & 852 \\
\hline
\end{tabular}


Table 4. Mean intake of dry matter (DM), organic matter (OM), NDF, net energy and $N$ and apparent digestibilities of $\mathrm{OM}, \mathrm{N}$ and NDF of the experimental rations.

\begin{tabular}{|c|c|c|c|c|c|c|c|}
\hline & \multicolumn{2}{|l|}{ Mean } & \multirow[t]{2}{*}{$\mathrm{SE}^{1}$} & \multicolumn{3}{|l|}{ Mean } & \multirow[t]{2}{*}{ SE } \\
\hline & F88 & S88 & & F89 & S89 & FS89 & \\
\hline \multicolumn{8}{|l|}{ Intake per cow $\left(\mathrm{kg} \mathrm{d}^{-1}\right)$} \\
\hline DM & 19.5 & 20.1 & 0.36 & $21.2^{\mathrm{a}}$ & $20.7 \mathrm{~b}$ & $20.7 \mathrm{~b}$ & 0.29 \\
\hline OM & $17.7 \mathrm{a}$ & $18.3^{\mathrm{b}}$ & 0.32 & 19.0 & 18.8 & 18.7 & 0.26 \\
\hline \multicolumn{8}{|l|}{$\mathrm{OM}$ as: } \\
\hline - herbage & 10.9 & 11.2 & 0.43 & 12.0 & 12.2 & 11.8 & 0.23 \\
\hline - concentrate & 5.4 & 5.6 & 0.22 & $6.4^{\mathrm{a}}$ & $5.9 \mathrm{~b}$ & $6.2^{c}$ & 0.04 \\
\hline$-\mathrm{Cr}_{2} \mathrm{O}_{3}$ pellets & 1.4 & 1.5 & 0.08 & $0.6^{\mathrm{a}}$ & $0.7 \mathrm{~b}$ & $0.7 \mathrm{~b}$ & 0.05 \\
\hline $\mathrm{OM} / \mathrm{kg} \mathrm{W0.75}$ & $0.147 \mathrm{a}$ & $0.152^{b}$ & 0.026 & 0.154 & 0.157 & 0.154 & 0.021 \\
\hline NDF & $9.2^{\mathrm{a}}$ & $8.3^{\mathrm{b}}$ & 0.17 & $9.3^{\mathrm{a}}$ & $7.4^{\mathrm{b}}$ & $8.1^{\mathrm{c}}$ & 0.13 \\
\hline Net energy (kVEM d-1) & $19.2^{\mathrm{a}}$ & $20.0^{\mathrm{b}}$ & 0.35 & 21.3 & 21.5 & 21.3 & 0.27 \\
\hline Nitrogen & $0.466^{\mathrm{a}}$ & $0.524^{b}$ & 0.010 & $0.590^{a}$ & $0.596^{\mathrm{a}}$ & $0.573^{b}$ & 0.01 \\
\hline \multicolumn{8}{|c|}{ Apparent digestibility $(\mathrm{g} \mathrm{kg-l})$} \\
\hline \multicolumn{8}{|l|}{ In vivo: } \\
\hline$-\mathrm{OM}$ & 727 & 746 & 12 & 723 & 734 & 733 & 8 \\
\hline$-N$ & $569 a$ & $637 \mathrm{~b}$ & 19 & $605 a$ & $643 \mathrm{~b}$ & $611^{\mathrm{a}}$ & 12 \\
\hline$-\mathrm{NDF}$ & 701 & 685 & 15 & $708^{a}$ & $661^{b}$ & $686^{c}$ & 10 \\
\hline \multicolumn{8}{|l|}{ In vitro: } \\
\hline$-\mathrm{OM}$ & 819 & 829 & 7 & 819 & 823 & 820 & 6 \\
\hline
\end{tabular}

1 Standard error of the mean.

a,b.c Means in the same row and year with different superscripts differ significantly $(P<0.05)$.

higher intake of OM and the higher energy content of the S88-diet. Intake of OM expressed per kg metabolic weight and intake of nitrogen and apparent digestibility of $\mathrm{N}$ were significantly $(P<0.05)$ higher on the S88-diet. Intake of NDF was lower on $\mathrm{S} 88$ than on F88 $(P<0.001)$. In vivo OM digestibility of the S88-diet tended to be higher than of the F88-diet $(P<0.06)$. In 1988 DM intake of cows on treatment F89 was higher $(P<0.05)$ than on the other treatments. Treatment FS89 resulted in a lower $(P<0.001)$ intake of $\mathrm{N}$ mainly due to the lower intake of OM. In $1989 \mathrm{~N}$ digestibility increased significantly as the level of starch in the diet increased. Intake and digestibility of NDF were significantly $(P<0.05)$ different between all treatments with the highest value for F89 and the lowest for S89.

\section{Yield and composition of milk and live weight}

The mean daily yield of milk, fat-corrected milk (FCM), milk fat, milk protein and composition of milk and live weight are shown in Table 5. Milk yield of cows fed the S88-diet was significantly $(P<0.025)$ higher than of cows fed the F88-diet (Table 4). In 1989 the milk yield was not significantly different between the three treat- 
Table 5. Mean yield and composition of milk and live weight of cows.

\begin{tabular}{|c|c|c|c|c|c|c|c|}
\hline & \multicolumn{2}{|l|}{ Mean } & \multirow[t]{2}{*}{$\mathrm{SE}^{1}$} & \multicolumn{3}{|l|}{ Mean } & \multirow[t]{2}{*}{$\mathrm{SE}$} \\
\hline & F88 & $\mathrm{S} 88$ & & F89 & S89 & FS89 & \\
\hline \multicolumn{8}{|l|}{ Yield $\left(k g d^{-1}\right)$} \\
\hline Milk & $25.8^{a}$ & $28.4^{b}$ & 1.24 & 30.9 & 31.6 & 30.8 & 1.10 \\
\hline FCM & 26.4 & 28.1 & 1.36 & 31.8 & 30.2 & 31.0 & 1.30 \\
\hline Fat & 1.074 & 1.112 & 0.063 & $1.294 \mathrm{a}$ & $1.172^{b}$ & 1.244 & 0.062 \\
\hline Protein & $0.887 \mathrm{a}$ & $0.982^{b}$ & 0.033 & 1.021 & 1.030 & 1.015 & 0.031 \\
\hline Fat + protein & 1.961 & 2.095 & 0.090 & 2.314 & 2.202 & 2.258 & 0.087 \\
\hline \multicolumn{8}{|c|}{ Milk composition ( $\mathrm{g} \mathrm{kg-l}$ ) } \\
\hline Fat & 41.5 & 39.2 & 1.5 & $41.9^{\mathrm{a}}$ & $37.0^{\mathrm{b}}$ & $40.5^{\mathrm{a}}$ & 1.3 \\
\hline Protein & 34.3 & 34.8 & 0.7 & 33.2 & 32.7 & 33.1 & 0.7 \\
\hline Live weight ( $\mathrm{kg}$ ) & 606 & 593 & 25 & 624 & 590 & 612 & 24 \\
\hline Change (kg wk-1) & -1.2 & -1.0 & - & +1.6 & +2.4 & +2.3 & - \\
\hline
\end{tabular}

1 Standard error of the mean.

a,b Means in the same row and year with different superscripts differ significantly $(P<0.05)$.

ments but tended to be higher $(P<0.06)$ on the S89-diet. Milk fat percentage was below $40 \mathrm{~g} \mathrm{~kg}^{-1}$ for the starchy diets (S88 and S89) and on S89 significantly $(P<0.05)$ lower than on F89. In 1989 the decrease in yield of milk on F89 was compensated by a higher fat concentration resulting in a higher yield of FCM than on S89. Yield of milk fat was higher on the F89-diet than on the S89-diet $(P<0.05)$, especially as a result of the higher milk fat concentration on F89. Milk protein concentration was unaffected by the source of carbohydrate. The difference in yield of milk protein between F88 and S88 $(P<0.001)$ can be attributed to the difference in milk yield. Mean live weight of the cows on treatment S89 was lower than on the other treatments. Mean live weight changes per week were low but tended to be negative in 1988 and positive in 1989.

\section{Discussion}

In 1988 the difference in energy and protein intake between the treatments confused the interpretation of the results with regard to the effects of different carbohydrate sources on the utilization of energy and protein in a herbage-based diet. Therefore, in 1989 an experiment was carried out in which concentrate allowances were supplied on the basis of an equal amount of energy and protein. In 1988 the higher protein intake on S88 was due to an unintentional high crude protein content of the hominy feed used in that concentrate. Based on the chemical composition of this hominy feed it seems likely that the feedstuff used in that experiment was in fact a mixture of hominy feed and maize gluten feed. For making a good comparison 
between fibre and starch in 1989 only maize meal was the principle ingredient in the starchy concentrate.

In 1988 crude protein content of herbage was low, possibly as a result of dry weather conditions with low temperatures during the experiment. Under such weather conditions, Deinum (1966) found a low herbage DM production and a low $\mathrm{N}$ uptake by the plant, which resulted in a low crude protein content.

\section{Intake and digestibility}

At the same DM intake of concentrates and $\mathrm{Cr}_{2} \mathrm{O}_{3}$ pellets, herbage DM intake was lower on F88-diet than on S88-diet. This indicates that the substitution of herbage by beetpulp is higher than by maize meal in the concentrates. However, Meijs et al. (1986) and Kibon et al. (1987) found a lower substitution rate when cassave (rapidly degradable starch) in concentrate-mixtures was replaced by beetpulp. It is possibly that the difference in rumen fermentation pattern between rapid and slowly degradable starch can explain the different effects of these supplements on DM intake of forages. Because more than $90 \%$ of starch from small grains (barley, cassava) is ruminally fermentable, but up to $40 \%$ of corn starch can escape ruminal fermentation (Ørskov, 1986).

Only in 1989 the digestibility of NDF was significantly $(P<0.05)$ higher on the fibrous diet as compared with the starchy diet. This indicates that the NDF digestibility of beetpulp was higher than of maize meal, which was also found by Varga et al. (1983). At the same digestibility of OM of the diet Huhtanen (1988) and Rymer et al. (1989) also found a lower digestibility of NDF when beetpulp was replaced by barley. A higher OM and a lower NDF digestibility on the starchy as compared with the fibrous diet suggest a higher digestibility of neutral detergent soluble components on the starchy than on the fibrous diets. Robinson et al. (1987) stated that at high levels of intake non-starch neutral detergent soluble components such as pectin and fat, which occurs in beetpulp, are less well digested than starch, and are more susceptible to depression in digestion. This phenomenon may be the reason why on the beetpulp diet the digestibility of OM was lower and the digestibility of NDF higher than on the starchy diet. In contrast with our findings, several research workers found that by replacing a barley concentrate with a beetpulp concentrate the OM digestibility of a straw-based diet increased (Istasse et al., 1986; Fahmy et al., 1984). They mentioned that on a barley diet a low rumen $\mathrm{pH}$ reduced the rate of digestion of fibre from straw. On a diet with alfalfa-haylage and corn silage, McCarthy et al. (1989) found a decrease in ruminal fibre degradation when barley replaced corn in the diet. It is likely that the differences in type of starch between the present and other research work can explain the differences in digestibilities of $\mathrm{OM}$ and NDF.

A higher apparent digestibility of nitrogen on starchy as compared with fibrous diets was also found by Robinson et al. (1986), Huhtanen (1988), Bhen-Ghedalia et al. (1989) and Rymer et al. (1989). Ben-Ghedalia et al. (1989) and Rymer et al. (1989) suggested that there are no real differences in true digestibility but that metabolic feacal $\mathrm{N}$ excretion is higher on the beetpulp than on the starchy diet. 


\section{Milk yield and energy and protein utilization}

The cows fed the S88-diet produced $2.6 \mathrm{~kg}$ more milk than the cows on the F88-diet, partly attributed to the higher intake of energy on the S88-diet. The other part might have been due to a higher intake of protein and/or starch on that diet. In 1989 there was no effect of carbohydrate source on milk yield at a level of concentrate inclusion of about $40 \%$. Sutton et al. (1987) fed cows diets containing $60 \%$ and $80 \%$ concentrates and observed a higher milk production at the highest rate of concentrate inclusion, when on energy basis a fibrous concentrate was replaced by a starchy concentrate. Furthermore, they found no effect of carbohydrate source on milk yield when cows received lower quantities of concentrates, which was in agreement with the results of Mayne et al. (1984) and Thomas et al. (1986). In our experiment the response in yield of milk and milk protein on the S88-diet might be attributed by an increased protein intake. That is likely because protein content of herbage DM in 1988 was relatively low (175 $\left.\mathrm{g} \mathrm{kg}^{-1} \mathrm{DM}\right)$.

By using the PDI system (Verite et al., 1979) on the F88- and the S88-diet the expected yield of milk protein was 954 and $1114 \mathrm{~g} \mathrm{~d}^{-1} \mathrm{cow}^{-1}$. At the start of the experiment the average yield of milk protein was $1115 \mathrm{~g} \mathrm{~d}^{-1} \mathrm{cow}^{-1}$, which means that only on the S88-diet the protein balance (protein supply-protein requirement) was near zero. For the F88-diet the protein balance was negative and resulted in a lower yield of milk protein. On that diet the PDI system calculated a lack of $\mathrm{N}$ rather than a lack of energy for microbial synthesis, while on S88 $\mathrm{N}$ and energy availibility were similar.

Beever et al. (1986) mentioned results from experiments of several researchers, who found a positive response on yield of milk and milk protein of dairy cows at pasture offered protein-rich supplements. Similar effects have been reported with lactating sheep (Penning et al., 1988). In some cases these responses were due to increased DM intake resulting in a reduced rumen residence time and a reduced protein degradation. In conclusion, it seems that there was no effect of carbohydrate source on yield of milk and milk protein, but that the increase was due to a combination of a higher energy and protein intake.

The difference in FCM production between F88 and S88 can be mainly (90 \%) explained by the difference in energy intake. In 1989 milk fat percentage decreased as the level of starch in the diet increased. Due to a higher fat percentage in the milk of cows fed the S89-diet, yield of FCM was higher than of cows fed the S89-diet. The reduced milk energy output on S89 as compared to F89 give little room for the assumption that the efficiency of dietary energy for milk production is higher on the fibrous than on the starchy diet.

Fibre content of the diet is a major factor influencing milk fat concentration (Sutton et al., 1987). For the treatments F89, S89 and FS89 the NDF content of the diet was 439, 358 and $391 \mathrm{~g} \mathrm{~kg}^{-1} \mathrm{DM}$, respectively. Fibre from forage in the diet was similar between the three diets at a value of $300 \mathrm{~g} \mathrm{~kg}^{-1}$ DM. At a level of $260 \mathrm{~g}$ NDF from forage (grass silage) in the diet Sutton et al., (1987) found no effect of carbohydrate source (beetpulp versus barley) on milk fat concentration. Finally at a total level of $312 \mathrm{~g} \mathrm{NDF}$ with about $130 \mathrm{~g}$ NDF from forage in the diet, Sutton 
et al. (1987) observed a negative effect of starch on milk fat concentration. In the present experiment with herbage as a forage, the negative effect of starch on milk fat concentration was measured at a higher level of NDF in the diet with a higher level of forage NDF. In agreement with Sutton et al. (1987) the much higher milk fat concentration on F89 clearly shows that fibre from beetpulp with little physical structure is more effective in preventing milk fat depression than starch. With a similar forage (grass silage)/concentrate ratio in the diet to that in the present experiments, Castle et al. (1981) and Mayne et al. (1984) found no difference in milk fat percentage on a fibrous (beetpulp) or a starchy (barley) concentrate. In contrast, fat concentration was markedly higher in the milk of cows given a concentrate mixture based on barley as compared with beetpulp as a supplement (Thomas et al., 1986). They have no clear explanation for this phenomenon.

In 1989 the milk protein concentration was not affected by the source of carbohydrate. This was in agreement with results of Castle et al. (1981) and Mayne et al. (1984). Thomas et al. (1986) found a lower milk protein concentration on a beetpulp diet as compared with a barley diet probably due to the inclusion of fat in the beetpulp diet. In 1989 the yield of milk protein between the two sources of carbohydrates was similar. For the three treatments F89, S89 and FS89 the PDI allowance was sufficient for producing 1114,1181 and $1132 \mathrm{~g}$ milk protein $\mathrm{d}^{-1}$ cow $^{-1}$.

With similar nitrogen intake (F89 and S89) the utilization of digested $\mathrm{N}$ ( = percentage of digested $\mathrm{N}$ excreted as milk-N) was significantly $(P<0.05)$ better on the beetpulp than on the starchy diet (45.1 versus $41.9 \%$ ). On F89 as compared with S89 the increase in $\mathrm{N}$ excretion in faeces corresponded with a decrease of $\mathrm{N}$ output in the urine. The latter suggest that the losses of ammonia in the rumen were smaller on the beetpulp than on the starchy diets. On the beetpulp diet, microbes might have captured more ammonia from degraded herbage protein than on the starchy diet. The amount of milk $\mathrm{N}$ produced per $\mathrm{g} \mathrm{N}$ consumed was almost similar for the different carbohydrate sources $(0.298$ versus 0.294 in 1988 and 0.271 versus 0.270 in 1989). Supplementing herbage-based diets with energy-rich and protein-low concentrates, these value improved to a level of 0.27 as compared to 0.17 on a diet of only herbage (van Vuuren et al., 1987). This improvement is probably attributed to the reduced intake of $\mathrm{N}$ and a reduction in rumen-degradable $\mathrm{N}$.

\section{Conclusions}

The results showed a significantly lower apparent digestibility of $\mathrm{N}$ and a higher NDF digestibility (only in 1989), when maize starch was replaced by beetpulp in concentrate mixtures as supplements in a herbage-based diet. The proportion of $\mathrm{N}$ excreted in faeces was higher on the beetpulp than on the starchy diets. The source of carbohydrates had no significant influence on the $\mathrm{N}$ conversion expressed as the proportion of $\mathrm{N}$ intake recovered as milk- $\mathrm{N}$. When compared with the $\mathrm{N}$ conversion of a diet containing only herbage, the $\mathrm{N}$ conversion was improved from 0.17 to 0.27 . Yield and concentration of fat in milk were depressed when maize replaced beetpulp in the concentrates. Milk protein content was not influenced by the sources of carbohydrates. In one experiment the higher protein intake resulted in a higher yield 
of milk and milk protein, presumably related to the low protein content of the herbage.

\section{Acknowledgements}

The authors acknowledge a large number of students for their contribution to the experimental and office work, the farm staff for care of the animals, the scientist computer services, the statistician and the laboratory workers, who performed a large number of chemical analyses. These experiments were financially supported by the Dutch Fund for Manure Research.

\section{References}

Alvey, N., N. Galwey \& P. Lane, 1982. An introduction to Genstat. Academic Press, London, 152 pp. Arriaga-Jordan, C. M. \& W. Holmes, 1986. The effect of concentrate supplementation on high-yielding dairy cows under two systems of grazing. Journal of Agricultural Science (Cambridge) 107:456-461.

Beever, D. E. \& R. C. Siddons, 1986. Digestion and metabolism in the grazing ruminant. In: L. P. Milligan, W. L. Grovum \& A. Dobson (Eds), Proceedings VIth International Symposium Ruminant Physiology, p. 479-497. Englewood, New Yersey.

Ben-Ghedalia, D., E. Yosef, J. Mikon \& Y. Est, 1989. The effect of starch- and pectin-rich diets on quantitives aspects of digestion in sheep. Animal Feed Science and Technology 24:289-298.

Blaxter, K. L., 1962. The energy metabolism of ruminants. Hutchinson \& Co,; London, 522 pp.

Castle, M. E., M. S. Gill \& J. N. Watson, 1981. Silage and milk production: a comparison between barley and dried sugar beet pulp as silage supplement. Grass and Forage Science 36:319-324.

Deinum, B., 1966. Climate, nitrogen and grass. I. Research into the influence of light intensity, temperature, water supply and nitrogen on the production and chemical composition of grass. Mededelingen Landbouwhogeschool Wageningen No 66-11, $91 \mathrm{pp}$.

Es, A. J. H. van, 1978. Feed evaluation for ruminants. 1. The system in use from 1977 onwards in the Netherlands. Livestock Production Science 5:331-345.

Fahmy, S. T. M., N. H. Lee \& E. R. Orskov, 1984. Digestion and utilization of straw. 2. Effect of different supplements on the digestion on ammonia-treated straw. Animal Production 38:75-81.

Huhtanen, P., 1988. The effects of barley, unmolassed sugar beetpulp and molasses supplements on organic matter, nitrogen and fibre digestion in the rumen of cattle given a silage diet. Animal Feed Science and Technology 20:259-278.

Istasse, L., G. W. Reid, C. A. G. Tait \& E. R. Orskov, 1986. Concentrates for dairy cows; effects of feeding method, proportion in diet and type. Animal Feed Science and Technology 15:167-182.

Kibon, A. \& W. Holmes, 1987. The effect of height of pasture and concentrate composition on dairy cows grazed on continuously stocked pastures. Journal of Agricultural Science (Cambridge) 109:293-301.

Mayne, C. S. \& F. J. Gordon, 1984. The effect of type of concentrate and level of concentrate feeding on milk production. Animal Production 39:65-76.

McCarthy, R. D., T. H. Klusmeyer, J. L. Vicini \& J. H. Clark, 1989. Effects of source of protein and carbohydrate on ruminal fermentation and passage of nutrients to the small intestine of lactating cows. Journal of Dairy Science 72:2002-2016.

Meijs, J. A. C., 1981. Herbage intake by grazing dairy cows. Agricultural Research Reports 909. Pudoc, Wageningen, $264 \mathrm{pp}$.

Meijs, J. A. C., 1986. Comparison of starchy and fibrous concentrates for grazing dairy cows. In: J. Frame (Ed.), Grazing, p. 129-138. Britisch Grassland Society, Hurley, UK.

Meijs, J. A. C. \& J. A. Hoekstra, 1984. Concentrate supplementation of grazing dairy cows. I. Effects of concentrate intake and herbage allowance. Grass and Forage Science 39:1-8. 
Orskov, E. R., 1986. Starch digestion and utilization in ruminants. Journal of Animal Science 63:1624-1634.

Penning, P. D., R. J. Orr \& T. T. Treacher, 1988. Responses of lactating ewes, offered fresh herbage indoors and when grazing, to supplements containing different protein concentrations. Animal Production 46:403-415.

Robinson, P. H., S. Tamminga \& A. M. van Vuuren, 1987. Influence of declining level of feed intake and varying the proportion of starch in the concentrate on rumen ingesta quantity, composition and kinetics of ingesta turnover in dairy cows. Livestock Production Science 17:37-62.

Rymer, C. \& D. G. Armstrong, 1989. Digestion of molassed sugarbeet pulp diets. Journal of Agricultural Science (Cambridge) 113:223-231.

Stakelum, G., 1986. Herbage intake of grazing dairy cows. 3. Effects of herbage mass, herbage allowance and concentrate feeding on the herbage intake of dairy cows grazing on mid-summer pasture. Irish Journal of Agricultural Research 25:179-189.

Stockdale, C. R., A. Callaghan \& T. E. Trigg, 1987. Feeding high energy supplements to pasture-fed dairy cows. Effect of stage of lactation and level of supplement. Australian Journal of Agricultural Research 38:927-940.

Sutton, J. D., J. A. Bines, S. V. Morant, D. J. Napper \& D. I. Givens, 1987. A comparison of starchy and fibrous concentrates for milk production, energy utilization and hay intake by Friesian cows. Journal of Agricultural Science (Cambridge) 109:375-386.

Thomas, C., K. Aston, S. R. Daley \& J. Bass, 1986. Milk production from silage. 4. The effect of the composition of the supplement. Animal Production 42:315-325.

Thomas, P. C. \& P. A. Martin, 1988. The influence of nutrient balance on milk yield and composition. In: P. C. Garnsworthy (Ed.), Nutrition and lactation of the dairy cow, p. 97-118. Butterworths, London.

Twigge, J. R. \& L. G. M. van Gils, 1988. Practical aspects of feeding protein to dairy cows. In: W. Haresign \& D. J. Cole (Ed.), Recent developments in ruminant nutrition 2, p. 196-212. Butterworths, London.

Varga, G. A. \& W. H. Hoover, 1983. Rate and extent of Neutral Detergent Fibre degradation of feedstuffs in situ. Journal of Dairy Science 66:2109-2115.

Verite, R., M. Journet \& R. Jarrige, 1979. A new system for the protein feeding of ruminants: the PDI system. Livestock Production Science 6:349-367.

Vuuren, A. M. van \& J. A. C. Meijs, 1987. Effects of herbage composition and supplement feeding on the excretion of nitrogen in dung and urine by grazing dairy cows. In: H. G. van der Meer, R. J. Unwin, T. A. van Dijk \& G. C. Ennink (Eds), Animal manure on grassland and fodder crops: Fertilizer or waste? p. 17-24. Martinus Nijhoff Publishers, Dordrecht. 